\title{
PERFORMANCE LEVELS OF FEMALE STUDENTS IN COMBINED TRACK-AND-FIELD EVENTS
}

\author{
Ladislava Doležajová ${ }^{1}$, Anton Lednický ${ }^{1}$, Martin Vaváček ${ }^{2}$ \\ ${ }^{1}$ Faculty of Physical Education and Sport, Comenius University in Bratislava, Slovakia \\ ${ }^{2}$ Faculty of Sports Studies, Masaryk University in Brno, Czech Republic
}

\begin{abstract}
Summary: The authors have evaluated the combined track-and-field events performed by the female students of the Faculty of Physical Education and Sport of Comenius University in Bratislava (CU FPES) in the years 2013 - 2017. The combined track-and-field events are an obligatory part of the final Athletics examination in the teacher-training study program. The selected disciplines reflect the first day of the men's decathlon with the exception of the last one, which is replaced by $800 \mathrm{~m}$. The number of points in the combined event enters into the overall assessment of the subject Didactics of Athletics II together with an oral examination. The authors analysed not only the total number of points in the pentathlon but also in the individual disciplines and their percentage share in the final result. They have discovered that the shot put and high jump are among the most stable disciplines. The greatest variance of the percentage share in the overall number of points was observed in the $100 \mathrm{~m}$ dash, $800 \mathrm{~m}$ and in the long jump. The performance of a high number of students (almost two-thirds) came below the average performance in the particular year as expressed in points.
\end{abstract}

Keywords: combined track-and-field events, CU FPES female students, physical performance, final athletics examination

DOI 10.2478/afepuc-2018-0006

(C) Acta Facultatis Educationis Physicae Universitatis Comenianae 


\section{Introduction}

The combined track-and-field events, or the modern pentathlon, are very popular with the audience nowadays. Ryba et al. (2002) note that the combined track-and-field events require an exceptional athletic versatility and they are the only athletic disciplines in which the final performance is expressed in points.

The assessment of the practical part of the Theory and Didactics of Athletics (in the past also Athletics IV, Didactics of Athletics II) as one of the mandatory subjects during the study at the Faculty of Physical Education and Sports of Comenius University in Bratislava (CU FPES) has undergone a number of modifications. These were prompted especially by the number of hours per semester allocated to the subject. A modified pentathlon has been in use since 2008. The disciplines reflect the first day of the men's decathlon with the exception of the last one, which is here replaced with an 800-metre run. The combined events form a part of the overall assessment together with an oral examination. Whereas in the past (Lednický 2003), with the minimum limit of 1,600 points, a deteriorating trend was recorded in the performance, the period observed in this study is characterised by a stabilisation of the average performance $(2013$ - 2017). The minimum number of points to meet the performance criteria is 1,500 points, which comprises $25 \%$ of the overall grade of the subject. A bonus of $1 \%$ is granted for each 25 points exceeding this limit to further the students' motivation to achieve the best performance possible. The students' performance is notably affected by the level of physical education at primary and secondary schools. According to findings (Koštial, Dremmelová \& Sedláček 2001), the number of students who did not participate in a regular training process was growing; they only became familiar with some disciplines (e.g. high jump, shot put) upon commencing studies at this faculty. The credit system, however, did not prove to be an incentive for the students to attempt to perform at their best in the individual disciplines. We often witnessed a situation when the final discipline was only run to earn the necessary number of points, in order to meet the 1,500 limit, or when a student started the discipline, but did not finish it because she'd already achieved the required limit after four disciplines. An important change in the assessment of the subject was the regulation which established that only the students taking the teacher-training program have to perform the final combined track-and-field events and the oral exam. These students usually do not devote themselves to a regular training process to such an extent as the students of the coachtraining program, and hence their performance is lower. On the other hand, there are several 
students in the individual groups, even ones with the Conditioning Coach specialisation, whose physical condition is better. At the Bratislava CU FPES the subject Athletics has always been evaluated comprehensively, the final grade calculated on the basis of the physical performance in the combined track-and-field events and theoretical knowledge demonstrated at the oral examination.

\section{Purpose}

The purpose of this study was to analyse the changes in the performance of the female students of the teacher-training program at the Bratislava CU FPES in the combined trackand-field events in $2013-2017$ and to indicate changes in the share the individual disciplines contribute to the overall result.

\section{Tasks}

1. To analyse the results of the combined events performed by the CU FPES female students in the years $2013-2017$.

2. To ascertain and compare the percentage share of the individual disciplines in the overall result of the combined event.

3. To determine the numbers of students with a result worse than the average performance in the particular year.

\section{Methods}

We observed the students' performance in the years 2013 - 2017, carrying out ex post facto research to solve these tasks. The groups observed were formed by students who had fulfilled the minimum requirement, that is 1,500 points, or who had a slightly lower performance recognised, given their health and/or other problems. Each group comprised between 13 and 21 students and basic mathematical and statistical characteristics were used when processing the results. The number of female students following a teacher-training program is lower than the number of male students, but it did not change in any substantial way (Lednický \& Doležajová 2016). However, most of them (70 - $75 \%)$ were working on this specialisation while studying another programme alongside (Coaching and Teaching or Sports and Health). 


\section{Results}

In the course of the period observed we researched the share of the individual disciplines in the overall result (Table 1). The average values have shown that as far as the percentage share is concerned, the most stable discipline is the shot put. The difference between the highest and the lowest contribution to the grand total of points was less than $1 \%$. The greatest difference was between the average values displayed in the $800 \mathrm{~m}$ (a difference of $5.9 \%)$.

Table 1

The average (x), maximum (max) and minimum (min) percentage share of the individual track-and-field disciplines in the overall result and the number (n) of female students tested in the observed period

\begin{tabular}{|l|l|c|c|c|c|c|}
\hline Discipline & \% share & $\begin{array}{c}\mathbf{2 0 1 3} \\
(\mathrm{n}=21)\end{array}$ & $\begin{array}{c}\mathbf{2 0 1 4} \\
(\mathrm{n}=17)\end{array}$ & $\begin{array}{c}\mathbf{2 0 1 5} \\
(\mathrm{n}=16)\end{array}$ & $\begin{array}{c}\mathbf{2 0 1 6} \\
(\mathrm{n}=16)\end{array}$ & $\begin{array}{c}\mathbf{2 0 1 7} \\
(\mathrm{n}=13)\end{array}$ \\
\hline \multirow{3}{*}{$100 \mathrm{~m}$} & $\mathrm{x}$ & 23.3 & 24.2 & 23.6 & 22.1 & 25.3 \\
\cline { 2 - 7 } & $\max$ & 27.5 & 32.8 & 29.1 & 32.3 & 31.7 \\
\cline { 2 - 7 } & $\min$ & 17.5 & 17.8 & 16.2 & 14.4 & 15.5 \\
\hline \multirow{3}{*}{ long jump } & $\mathrm{x}$ & 18.6 & 18.8 & 17.5 & 15.6 & 17.5 \\
\cline { 2 - 7 } & $\max$ & 24.9 & 22.5 & 22.0 & 21.0 & 28.7 \\
\cline { 2 - 7 } & $\min$ & 12.2 & 14.8 & 12.1 & 9.2 & 8.3 \\
\hline \multirow{3}{*}{ shot put } & $\mathrm{x}$ & 21.1 & 20.9 & 19.3 & 20.2 & 21.1 \\
\cline { 2 - 7 } & $\max$ & 27.5 & 25.8 & 24.7 & 33.1 & 26.6 \\
\cline { 2 - 7 } & $\min$ & 16.5 & 15.9 & 13.1 & 13.8 & 16.6 \\
\hline \multirow{3}{*}{$800 \mathrm{~m}$} & $\mathrm{x}$ & 20.0 & 17.3 & 19.8 & 20.4 & 20.1 \\
\cline { 2 - 7 } & $\max$ & 28.2 & 30.1 & 23.7 & 24.9 & 28.8 \\
\cline { 2 - 7 } & $\min$ & 15.4 & $0 / 11.9$ & 15.2 & 14.0 & 15.3 \\
\cline { 2 - 7 } & $\mathrm{x}$ & 17.0 & 18.9 & 19.9 & 21.6 & 15.8 \\
\cline { 2 - 7 } & $\max$ & 33.9 & 37.5 & 26.1 & 36.7 & 33.9 \\
\hline & $\min$ & 1.4 & $0 / 9.9$ & 10.9 & 7.2 & 8.1 \\
\hline
\end{tabular}

However, more precise information about the performance is provided by the maximum and minimum percentage shares in the overall result. From Tab. 1 it follows that some students earned more than one-third of the points in a single discipline. The minimum values of the share fell as low as zero in some cases (in the high jump, in a case when no valid successful attempt was recorded, and in the $800 \mathrm{~m}$ ). In such cases we also provided the second lowest share of the discipline in the overall result. As for the endurance discipline, given the low values of the minimum share it is obvious that in many cases the students strive 
only to meet the required limit in the combined events and often adapt the quality of the run in the last discipline to the number of points still needed.

The total number of points of the average performances was stable over the level of 1,700, with the exception of year 2015 (Table 2). This result, however, was only achieved thanks to some individuals who earned a number of points markedly higher than the average result of the whole group. The minimum values are around the required limit of 1,500 points every year with the exception of the years 2016 and 2017, when even a worse result was accepted. The smallest performance difference $\left(p_{d}\right)$ in the results occurred in $2017\left(p_{d}=509\right.$ points). On the contrary, the greatest difference occurred in 2015 ( $\mathrm{p}_{\mathrm{d}}=932$ points).

Table 2

The average (x), maximum (max) minimum ( $\mathrm{min}$ ) number of points in the women's combined events; the range of variation $\left(p_{d}\right)$ the number $(n)$ of female students tested in the observed period. In some cases a lower score was allowed due to health issues (*).

\begin{tabular}{|l|c|c|c|c|c|}
\hline & $\begin{array}{c}\mathbf{2 0 1 3} \\
(\mathrm{n}=21)\end{array}$ & $\begin{array}{c}\mathbf{2 0 1 4} \\
(\mathrm{n}=17)\end{array}$ & $\begin{array}{c}\mathbf{2 0 1 5} \\
(\mathrm{n}=16)\end{array}$ & $\begin{array}{c}\mathbf{2 0 1 6} \\
(\mathrm{n}=16)\end{array}$ & $\begin{array}{c}\mathbf{2 0 1 7} \\
(\mathrm{n}=13)\end{array}$ \\
\hline $\mathrm{x}$ & $1,722.5$ & $1,732.5$ & $1,862.6$ & $1,778.1$ & $1,703.2$ \\
\hline $\max$ & 2,090 & 2,103 & 2,449 & 2,324 & 1,962 \\
\hline $\min$ & 1,510 & 1,526 & 1,517 & $1,439^{*}$ & $1,453^{*}$ \\
\hline $\mathrm{p}_{\mathrm{d}}$ & 580 & 577 & 932 & 885 & 509 \\
\hline
\end{tabular}

For the 100-metre dash we recorded the difference of $3.2 \%$ between the highest and the lowest share in the total result of the combined events in the observed period. The average performance was awarded around $400-444$ points, that is the performances themselves were around 14.9 to $15.3 \mathrm{~s}$. The best performances differed markedly $(13.2 \mathrm{~s} ; 14.1 \mathrm{~s})$, the worst being 16.1 to 16.7 s. It is interesting that in the past this discipline (Doležajová \& Lednický, 2015) had a much greater share in the overall result $(27.7 \%$ in 2009) in the women' pentathlon. We recorded the greatest difference between the best and the worst performances $(3.3 \mathrm{~s})$ in 2016 , the smallest $(2.0 \mathrm{~s})$ in 2013. 


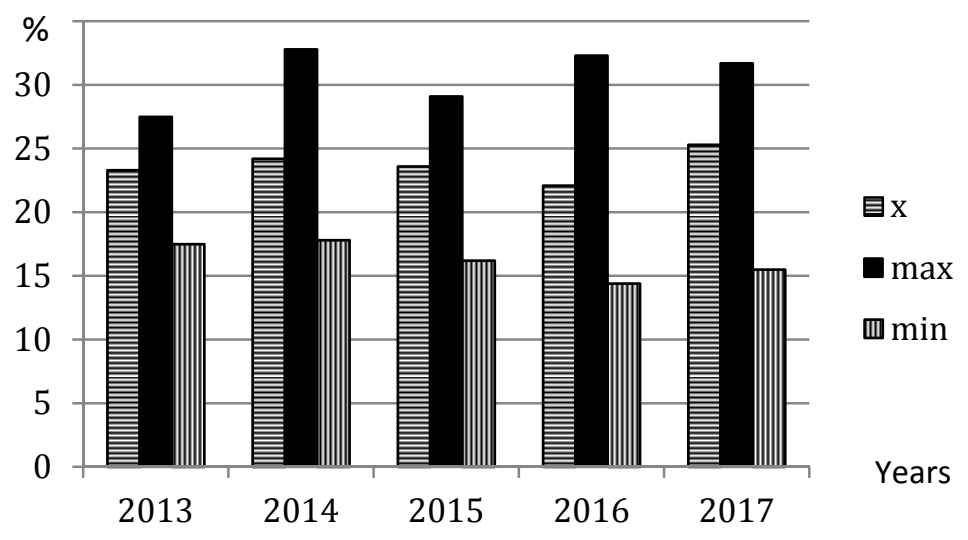

Figure 1

Average (x), maximum (max) and minimum (min) point values in the 100-metre dash

The long jump, also due to its technical exactingness, has a lower percentage share in the pentathlon result $(17.5-18.8 \%)$. In a single attempt, the students fail to combine the correct run-up with the take-off without an over-step or without leaping from too far behind. The performances often do not correspond to the results in the 100-metre dash. For instance, we recorded $13.2 \mathrm{~s}$ for $100 \mathrm{~m}$, but the same student only achieved $434 \mathrm{~cm}$ in the long jump. At the same time, this discipline carries a great weight as far as points are concerned (Ryba \& Jón 2002). The average performance was around $400 \mathrm{~cm}$. The best performance in the observed period was $492 \mathrm{~cm}$ in 2015; the worst was $322 \mathrm{~cm}$ in 2016 . The greatest performance difference was $136 \mathrm{~cm}$, occurring in the years 2015 and 2016.

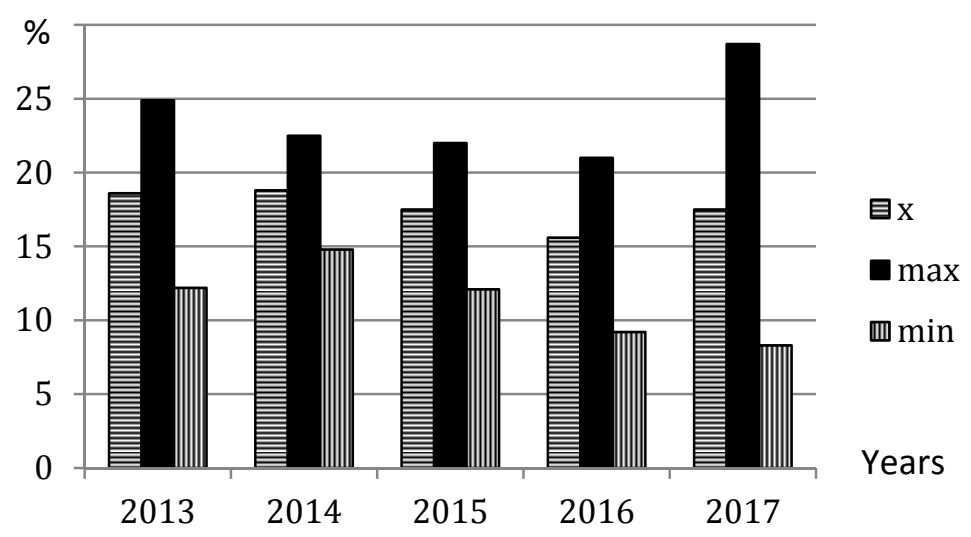

Figure 2

Average (x), maximum (max) and minimum (min) point values in the long jump

The most dramatic difference between the best and the worst performances was as much as 229 points in 2016, which represents $357 \mathrm{~cm}$. Its share in the overall performance is consistent around $19.3-21.1 \%$ (Table 1). As far as performance is concerned, it was around 
the average level of $730-740 \mathrm{~cm}$. The best performance in the observed period was $9.42 \mathrm{~m}$ in 2017 and the worst was in 2016, when a throw of only $5.61 \mathrm{~m}$ was recorded.

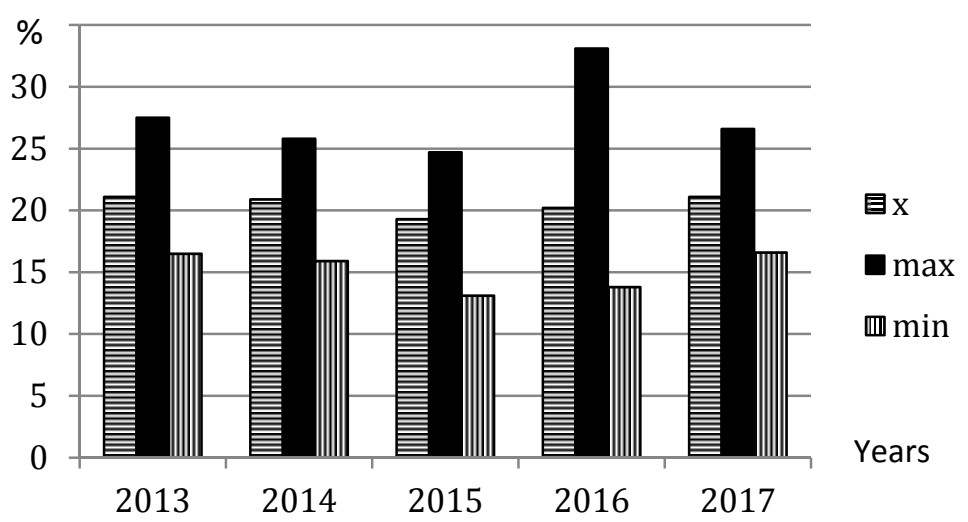

Figure 3

Average (x), maximum (max) and minimum (min) point values in the shot put

The high jump belongs among the disciplines, in which there is no great difference between the best and the worst performances, that being in the region of 238 to 390 points. The average performance $(120 \mathrm{~cm})$ is markedly influenced by failed attempts at the basic height of $110 \mathrm{~cm}$. The most successful attempt came over $140 \mathrm{~cm}$ every year, with the exception of 2017. The share of this discipline (Table 1) was stable around $20 \%$; this discipline displayed the second smallest variance in the share $(2.1 \%)$.

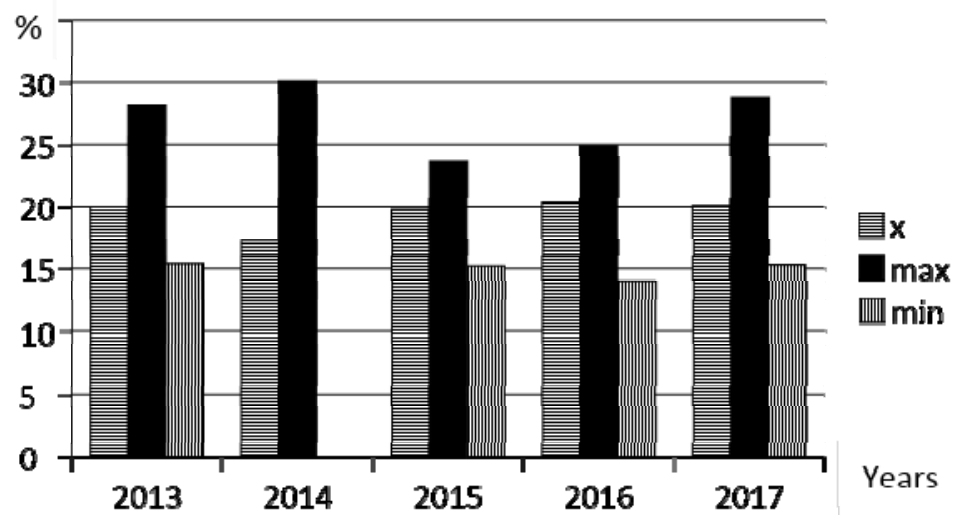

Figure 4

Average (x), maximum (max) and minimum (min) point values in the high jump

When calculating the difference we excluded the zero values of the students who, due to various reasons, did not finish the discipline. In the years 2013 and 2016 the difference was more than 500 points, in the other years it was around 350 points. The average performance was in the range of 3:00-3:20 min. The greatest difference between the best and the worst performances (2:30 minutes) was recorded in 2017 . The average share in the overall result 
changed markedly (difference of $5.9 \%$ ), but we have also recorded results in which one-third of the total number of points earned was made up in particular by points received for the $800 \mathrm{~m}$

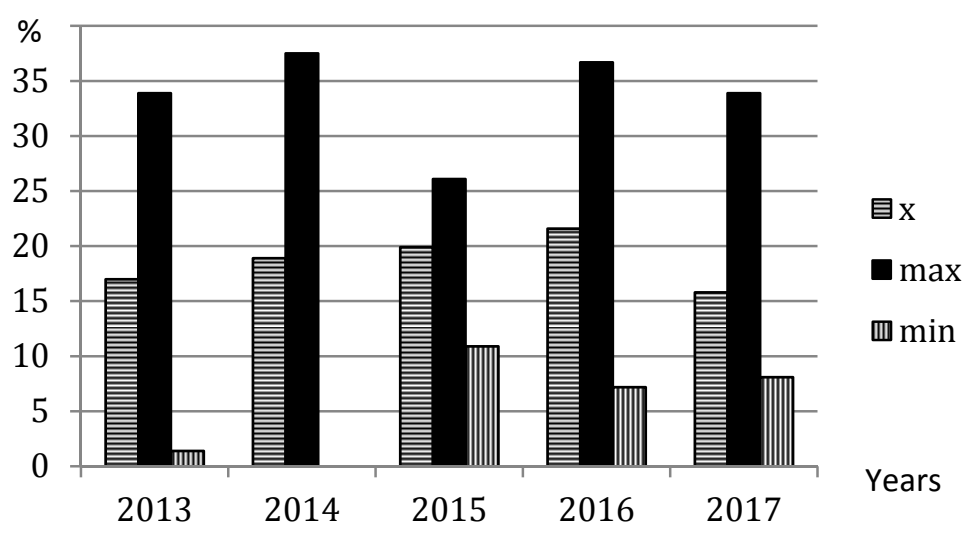

Figure 5

Average (x), maximum (max) and minimum (min) point values in the 800-metre run

Although the average performances in the combined track-and-field events were at the level of around 1,700 points, this level was achieved thanks to outstanding performances of some individuals. Table 3 shows the numbers of students in each year whose results were worse than the average performance in the given year.

Table 3

Average performances in the combined track-and-field events and the number of students whose performance was worse than average, the total percentage of worse than average performances (\%) and the number (n) of female students tested in the observed period

\begin{tabular}{|c|c|c|c|c|c|}
\hline & $\begin{array}{c}\mathbf{2 0 1 3} \\
(\mathrm{n}=1)\end{array}$ & $\begin{array}{c}\mathbf{2 0 1 4} \\
(\mathrm{n}=17)\end{array}$ & $\begin{array}{c}\mathbf{2 0 1 5} \\
(\mathrm{n}=16)\end{array}$ & $\begin{array}{c}\mathbf{2 0 1 6} \\
(\mathrm{n}=16)\end{array}$ & $\begin{array}{c}\mathbf{2 0 1 7} \\
(\mathrm{n}=13)\end{array}$ \\
\hline Average performance & 1722 & 1732 & 1862 & 1778 & 1703 \\
\hline Number of worse performances & 12 & 11 & 9 & 11 & 8 \\
\hline$\%$ & 57.1 & 64.7 & 56.3 & 68.8 & 61.5 \\
\hline
\end{tabular}

\section{Discussion}

The results of the track and field showed to the students the state of their physical condition and their level of mastering the techniques of the individual athletic disciplines. These factors are the prerequisites of independently teaching classes and demonstrating the exercises to one's own students. We are also aware that the differences in the performance 
are heavily influenced by the interest of the best ones in each group to achieve the best result possible instead of just meeting the required limit.

Besides the prerequisite of strength in long jump, the shot put also requires an adequate level of mastering the technique. That is why the female students make use of the option to throw from the lateral or the frontal position only. We may say that, as far as the percentage expression of the points earned is concerned, it belongs among the most stable disciplines (the difference between the highest and the lowest share was $0.9 \%$ ).

The preparation for the track and field also faces the problem of insufficient number of hours allocated to it, which tends to result in a poor mastering of technique in the more demanding disciplines. Problems have been recorded especially in field disciplines. The most discussed discipline is the 800-metre run: although it carries a great weight in points, many students could not overcome the unpleasant feelings of endurance load and their performance was below average. For some, the resulting total number of points from a combined event served as a good basis for receiving a high final assessment grade of the subject. The 800metre run is one of the less popular, but better valued parts of the combined events. From this also follow great differences in the points earned, which changed from year to year. There were also cases, however, when even students earning a high number of points did not prove to possess sufficient theoretical knowledge at the examination, which then led to them being awarded an average grade in total. But there have also been the opposite situations when a student with a minimum basis following the track and field received a final grade higher than the average namely thanks to the oral examination.

We are thus certain that to replace the 400-metre run with the endurance run was the right thing to do. Thanks to this discipline even those students who did not achieve excellent results in the speed-strength disciplines earned the required limit of 1,500 points. Despite the fact that the analysis of this discipline in the teaching process and the sports practice has been dealt with by several authors (Jílek 2009; Rošková 2013, 2014; Vindušková 2015), mutual comparison of the results is complicated, given the variety of the individual disciplines in the combined event. Despite the teachers' efforts to motivate the students by granting additional points for a better performance in the combined event, most of them were happy to meet the minimum required norm.

\section{Conclusions}


1. Following the analysis of the performance level of the CU FPES students in the combined track-and-field events we can say that the credit form of studies did not provide an impulse towards an improvement of performance. The tested students displayed general performance problems, and even motivation issues.

2. The level of performance in the combined track-and-field events was constant, on the level of around 1,700 points, but this result was achieved thanks to excellent performances of some individuals.

3. In the individual disciplines, the performance was approaching the level of credit requirements, but there were also cases when the students did not achieve this level in the field events and had no strong discipline to compensate for this failing.

4. The effort to increase the students' motivation by awarding an additional $1 \%$ for each 25 points so that they would make an effort to achieve their best performance often produced no effect; every year there were students who after meeting the limit of 1,500 points decided not to follow through with the final discipline.

5. This fact reflected in the number of those who achieved a performance worse than the average. In some of the years their share was as high as $68 \%$.

\section{References}

1. JÍLEK, M., 2009. Analýza vývoje výsledků studentů KTVS PDF UHK v jednotlivých disciplínach desetiboje v letech 2002 - 2009. In: Atletika 2009. Banská Bystrica: KTVŠ FHV UMB BB. 2009, pp. 264-273. ISBN 978-80- 8083-889-8.

2. KOŠTIAL, J., I. DREMMELOVÁ \& J. SEDLÁČEK, 2001. Úroveň všeobecnej pohybovej výkonnosti prijatých uchádzačov o štúdium na FTVŠ UK v Bratislave. In: Testovanie motorických schopností testami Eurofit a iných metodik. Proceedings from a specialist seminar organised by the Slovak University of Technology. Bratislava, pp.7681.

3. LEDNICKÝ, A., 2003. Zmeny výkonnosti študentov FTVŠ UK v atletickom pät'boji. In: Atletika 2003 [electronic source]. Brno: Masarykova univerzita.

4. LEDNICKÝ, A. \& L. DOLEŽAJOVÁ, 2016 Úroveň výkonnosti študentov FTVŠ UK v atletickom viacboji. In: Atletika 2016. Bratislava: ICM Agency, pp. 121-128.

5. DOLEŽAJOVÁ, L. \& A. LEDNICKÝ, 2015. Atletický viacboj - významná súčast' hodnotenia študentiek FTVŠ UK. Česká kinantropologie. č. 3. 
6. ROŠKOVÁ, M., 2013. Analýza úrovne výkonnosti v atletickom 5-boji študentiek KTVŠ FHV UMB v Banskej Bystrici. In: Atletika 2013. Nitra: KTVŠ PF UKF, pp.164-171. ISBN 978-80-8141-048-2.

7. ROŠKOVÁ, M., 2014. Analýza vývoja výkonnosti v jednotlivých disciplínach atletického 5-boja poslucháčov KTVŠ FF UMB v rokoch 2010 - 2014. In: Atletika 2014. Banská Bystrica: KTVŠ FHV UMB BB, pp. 431-440. ISBN 978-80-8141-076-5.

8. RYBA, J. et al., 2002 Atletické víceboje. Praha: Olympia. ISBN 80-7033-584-X.

9. RYBA, J. \& J. JÓN, 2002. Historie sedmiboje. In: RYBA, J. et al. Atletické víceboje. Praha: Olympia, pp. 125-127. ISBN 80-7033-584-X.

10. VINDUŠKOVÁ, J., 2015. Bodová strukturavýkonů v desetiboji. In: Atletika 2015. Praha. Proceedingsfrom a conference. ISBN 978-80-904237-3-2. 